\title{
The native Palythoa caribaeorum overgrows on invasive species in the intertidal zone
}

Received: 1 October 2008/Accepted: 1 November 2008/Published online: 14 November 2008

(C) Springer-Verlag 2008
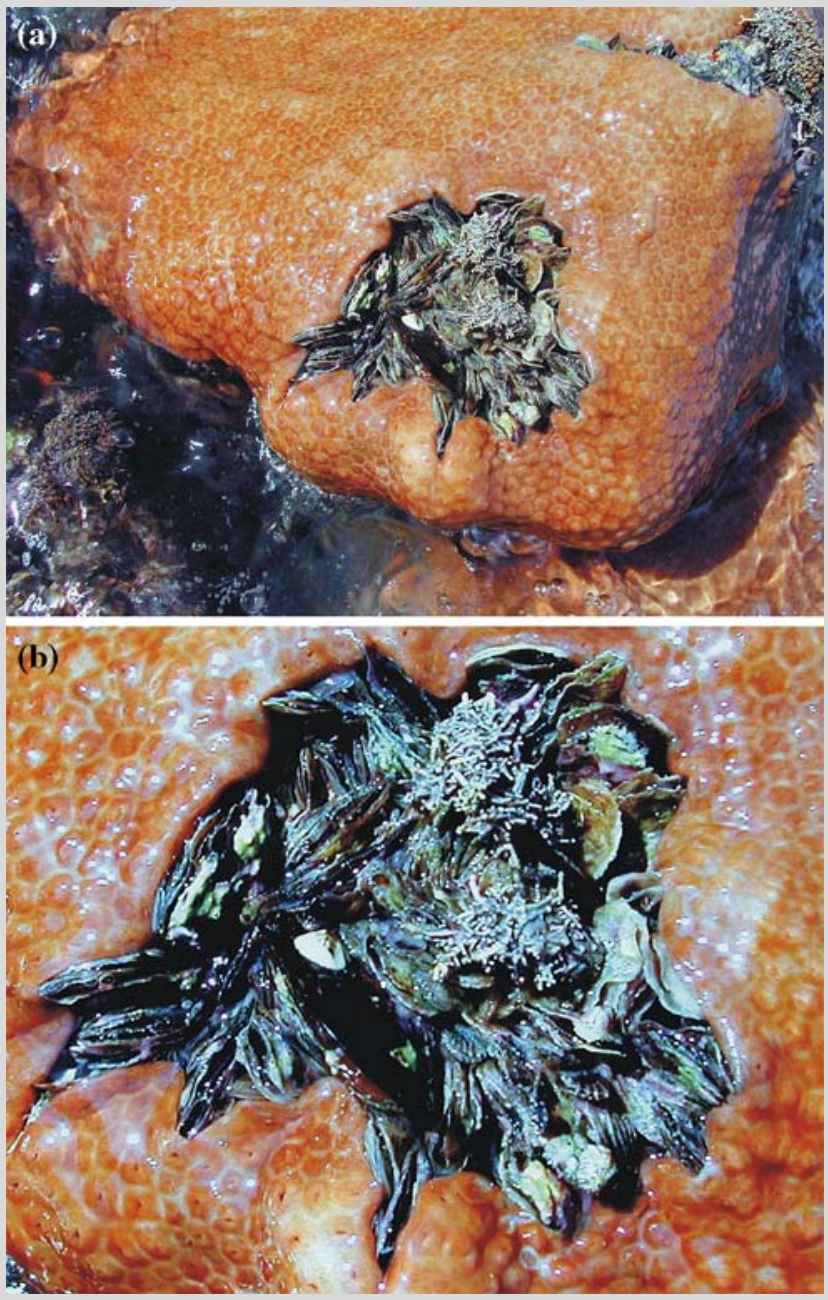

Overgrowth is a non-symbiotic association between living organisms (epibionts) on the surface of the hosts (basibionts). This association is known to affect the fitness of the basibionts in terms of reducing their growth rate and survivorship and to alter the interactions between the organisms and their environment (Wahl 2008). Colonies of the native encrusting zoanthid Palythoa caribaeorum (Duchassaing \& Michelotti 1860), a species typical of the infralittoral zone, reported as an aggressive competitor for vital resources such as space, dominate large areas on tropical and temperate shallow reefs. Yet, the ecological role that this species fulfills on reef communities of Brazilian rocky shores (southwestern Atlantic) has been scarcely studied to date. The bicolor purse-oyster, Isognomon bicolor (C.B. Adams 1845), is a Caribbean species first introduced in the Brazilian coast before 1990, presumably through transport in ballast water tanks or ship hulls. This bivalve is known to outcompete native and established intertidal species, including the commercially exploited brown mussel, Perna perna (Linnaeus 1758). Records of I. bicolor at the rocky shores of Forno Inlet (Arraial do Cabo, Rio de Janeiro state, southeastern Brazil), show that this bivalve can monopolize colonization space at the intertidal zone, probably preventing native species from settling. Colonies of $P$. caribaeorum were recorded for the first time overgrowing and killing articulated coralline algae (Amphiroa and Jania sp.) and I. bicolor on the mid- and lower-intertidal fringes (Fig. 1). The presence of the invasive $I$. bicolor seems to be a facilitating factor, allowing $P$. caribaeorum to extend its zone of occurrence upward into the intertidal zone.

Fig. 1 a Colonies of Palythoa caribaeorum overgrowing on intertidal Isognomon bicolor bank, b close-up of overgrown I. bicolor

\section{Reference}

Wahl M (2008) Ecological lever and interface ecology: epibiosis modulates the interactions between host and environment. Biofouling 24:427-438

J. P. Mendonça-Neto ( $₫)$ · B. A. P. da Gama

Departamento de Biologia Marinha, Universidade Federal Fluminense, PO Box 100644, CEP 24001-970 Niterói, RJ, Brazil e-mail: zepolicarpo@gmail.com 